\title{
Geochronology of alkali volcanism in Oki-Dogo Island, Southwest Japan: Geochemical evolution of basalts related to the opening of the Japan Sea
}

\author{
Kozo Uto, ${ }^{1}$ Eirchi TAKahashi, ${ }^{2}$ EIzo NAKAMURA ${ }^{3}$ and ICHIRo KANEOKA ${ }^{4}$ \\ ${ }^{1}$ Geological Survey of Japan, Tsukuba, Ibaraki 305, Japan \\ ${ }^{2}$ Faculty of Science, Tokyo Institute of Technology, Meguro, Tokyo 152, Japan \\ ${ }^{3}$ Institute for Study of the Earth's Interior, Okayama University, Misasa, Tottori 682-02, Japan \\ ${ }^{4}$ Earthquake Research Institute, University of Tokyo, Bunkyo, Tokyo 113, Japan
}

(Received July 24, 1993; Accepted September 13, 1994)

\begin{abstract}
Geochronological and geochemical studies were performed on alkali volcanic rocks from Oki-Dogo Island, locating about $60 \mathrm{~km}$ off the coast of Southwest Japan inside the Japan Sea. There are big differences both in age and in geochemistry between the oldest alkali rocks and the younger rocks; the former having significant $\mathrm{Nb}$ - and Ta-deletion and $\mathrm{Ba}$ - and $\mathrm{K}_{2} \mathrm{O}$-enrichment erupted at $19-18 \mathrm{Ma}$ when the opening of the Japan Sea was ongoing, while the latter with no Ta-depletion were active between 5.5-0.6 Ma considerably after the cessation of the rifting activity. Syn-extensional rocks should not have erupted in the active subduction zone but are probably originated from or at least contaminated by the lithosphere beneath the early Proterozoic crust. The lithosphere is considered to have suffered mantle metasomatism to form phlogopite selectively enriched in $\mathrm{Ba}$ and $\mathrm{K}_{2} \mathrm{O}$ by fluids, which had been released from previous subductions at the Asian continental margin. Partial meting of such lithospheric mantle during the active rifting was essential for the generation of $\mathrm{Ba}$ - and $\mathrm{K}_{2} \mathrm{O}$-enriched alkali basalt magmas. The younger basaltic rocks are probably originated either from the asthenosphere or the deeper plume mantle. A suite of volcanic rocks from mugearite through trachyte to alkali rhyolite gave concordant ages of 5.5-5.4 Ma. These ages suggest that a previously reported $\mathrm{Rb}-\mathrm{Sr}$ whole rock age of $6.8 \pm 0.3 \mathrm{Ma}$ does not represent the age of eruption and is probably disturbed by magma mixing between basic and acidic end members.
\end{abstract}

\section{INTRODUCTION}

Oki-Dogo Island is a small island in the Japan Sea, about $60 \mathrm{~km}$ off coast of Southwest Japan (Fig. 1). This island is well known for its bearing some alkali basalt lava flows with abundant mantle-derived spinel lherzolite nodules (Takahashi, 1978), and also for the existence of the Early Proterozoic metamorphic complex (Tanaka and Hoshino, 1987). The metamorphic complex is considered to be a continental fragment drifted away from the main Asian continent when the opening of the Japan Sea occurred (Tamaki, 1988). Various kinds of Neogene-Quaternary volcanic rocks crop out on this island covering the pre-Tertiary basement rocks and Paleogene calc- alkalic volcanic rocks (Uchimizu, 1966; Yamazaki et al., 1991). They are mainly alkali volcanic rocks ranging from $\mathrm{SiO}_{2}$-undersaturated alkali basalts through mugearite and trachyte to $\mathrm{SiO}_{2}$ oversaturated alkali rhyolites (Uchimizu, 1966; Xu, 1988). Geochemical studies on such alkali volcanic rocks (Xu, 1988; Nakamura et al., 1989) have clarified that older alkali basaltic rocks have geochemical signature similar to subduction-related basalts, while younger ones to within-plate basalts. Biostratigraphic information suggests that older basalts erupted in early Miocene (Yamazaki et al., 1990, 1991), while limited $\mathrm{K}-\mathrm{Ar}$ and $\mathrm{Rb}-\mathrm{Sr}$ age data on younger volcanic rocks span between 6.8 and 0.85 Ma (Kaneoka and Ozima, 1970; Kaneoka et al., 1977; Iwata et al., 1988; Fujimaki et al., 


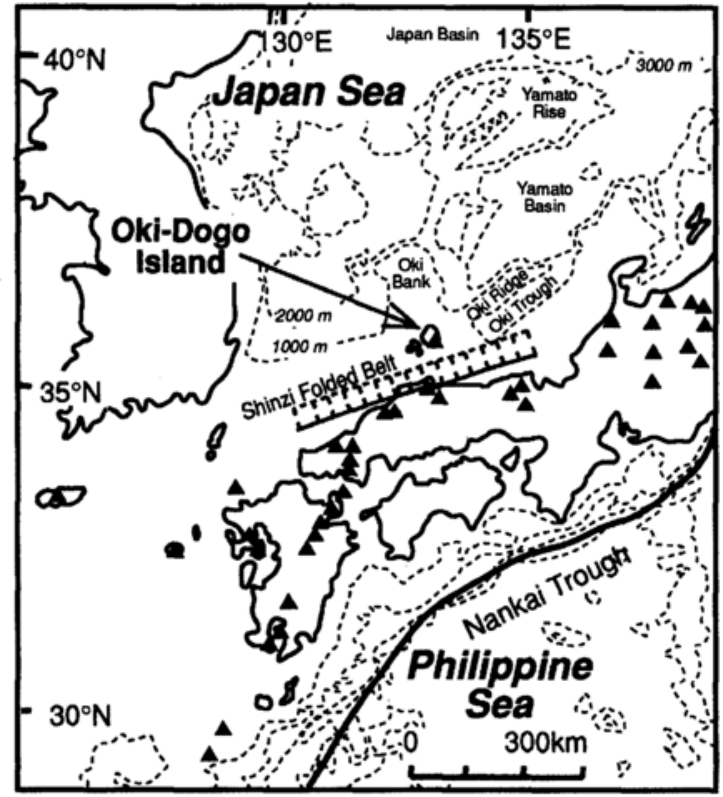

Fig. 1. Index map of Oki-Dogo Island. Solid triangles show localities of Quaternary volcanoes in SW Japan. Bathymetric counters of every $1,000 \mathrm{~m}$ are shown by dotted lines.

1989). As the active rifting and the opening of the Japan Sea are believed to have occurred during early to middle Miocene time, the geochemical difference between the older and younger volcanic rocks might be related to such a tectonic event.

In this paper, we give new $\mathrm{K}-\mathrm{Ar}$ age data for some volcanic rocks from Oki-Dogo with major and trace element chemistry data, and discuss the time progressive variations in magma chemistry and speculate their origins related to the back-arc rifting behind the Japanese Islands.

\section{TeCtonic SeTting}

The Japan Sea is a back-arc basin behind the Japanese Islands, and many structural highs and basins were recognized by submarine topographic and seismic profile studies (Tamaki, 1988) (Fig. 1). Some large scale topographic highs, like Yamato Rise, are considered to be continental fragments left behind when Japanese Islands drifted away from the mainland Asia (Tamaki,
1988).

Oki-Dogo Island locates about $60 \mathrm{~km}$ off the coast of Southwest Japan, resting on a submarine topographic high extending in N-S direction from Shimane Peninsula to Oki Bank, together with Oki-Dozen Island, another island made up with late Miocene alkalic volcanics (Tiba, 1975; Wada et al., 1990). The exposure of the lower Proterozoic gneiss in the northeastern part of the OkiDogo Island (Tanaka and Hoshino, 1987) suggest that Oki Bank is one of continental fragments mentioned above (Tamaki, 1988). This submarine high bounds the western end of the southernmost submarine graben in the Japan Sea, Oki Trough.

To the south of Oki Trough, there runs an E-W trending buried graben between Oki-Dogo Island and the mainland SW Japan. This graben runs from the off coast of the western part of Honshu for about $500 \mathrm{~km}$ in length. Early to Middle Miocene sediments and volcanics completely fill up the graben where granitic basements subsided more than 1,000 $\mathrm{m}$ (Yamauchi and Yoshitani, 1981; Tanaka and Ogusa, 1981; Kano and Yoshida, 1985), and the most subsided southern part was turned into a folded zone, called Shindi folded belt (Otuka, 1939). The volcanic activity in and around this graben started about $24 \mathrm{Ma}$ with progressive rifting (Kano, 1991) and ceased at 15-14 Ma, according to the radiometric age constraints given by Kano and Nakano (1985) and Uto (1989). This graben should be the southernmost constituent of a "Basin and Range" type rift graben system formed during the opening of the Japan Sea.

There have been many arguments when and how the back-arc opening occurred behind the Japanese Islands (Otofuji et al., 1985; Tamaki, 1986, 1988). Recent studies on Cenozoic stratigraphy of the Japanese Islands (Kano et al., 1991), ${ }^{40} \mathrm{Ar}-{ }^{39} \mathrm{Ar}$ dating of submarine volcanic rocks from the Japan Sea (Kaneoka et al., 1990, 1992), and results of Ocean Drilling Project (Jolivet and Tamaki, 1992) suggest that the back-arc opening started in Early Miocene and almost ceased in Middle Miocene. 


\section{GeOLOGic OUTLINE}

The outline of geology of Oki-Dogo Island (Fig. 2), combined with previous works and current age determinations, is as follows:

Basement rocks of Oki-Dogo Island are Proterozoic metamorphic rocks whose Nd-Sm wholerock ages are about $2 \mathrm{Ga}$ (Tanaka and Hoshino, 1987), and granitic rocks of Palaeozoic and Neogene age (Tainosho et al., 1991). These rocks are exposed on the northeastern part of the Island. Paleogene to Early Miocene sedimentary rocks and intercalating calc-alkalic volcanic rocks are distributed surrounding the basement rocks.

The oldest alkali volcanic rocks are subaque- ous lavas and volcaniclastics in the Kori Formation (KF), which sporadically appear in various parts of the Island beneath the thick coverage of younger volcanic products (Yamazaki, 1991; Yamazaki et al., 1990, 1991). Even though a fission-track zircon age of $13.7 \pm 0.7 \mathrm{Ma}$ is obtained for a tuff intercalated in trachybasalts (Yamazaki and Ganzawa, 1989), Yamazaki et al. $(1990,1991)$ and Yamazaki (1991) assigned these alkali basaltic rocks to the lower Miocene according to the diatom biostratigraphy. Chemistry of these volcanic rocks is quite different from the younger alkali volcanics, and $\mathrm{Xu}$ (1988) called these rocks as shoshonite or banakite.

After a long erosional interval, three groups of

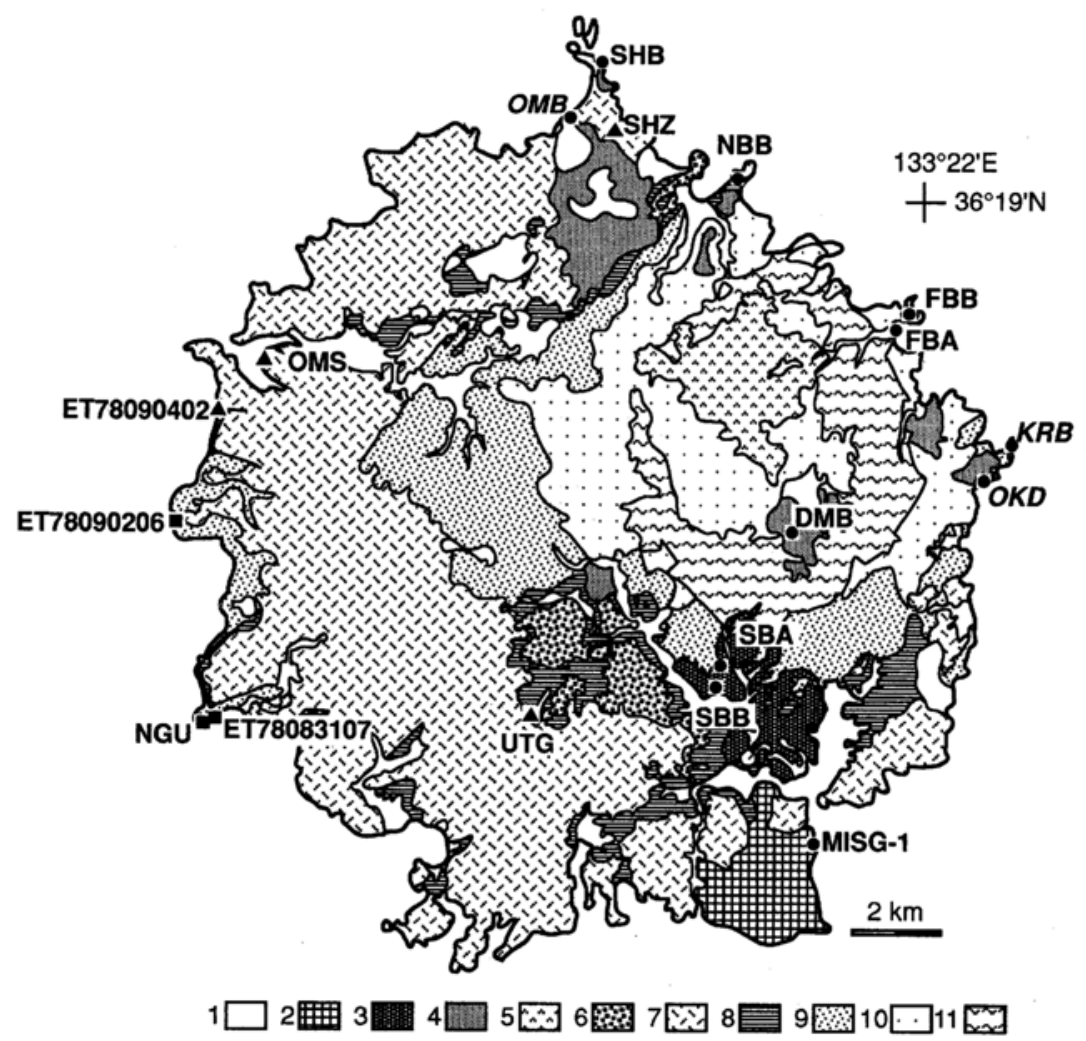

Fig. 2. Generalized geologic map of Oki-Dogo Island (modified after Yamazaki et al., 1991; Uchimizu, 1966) along with sample localities. 1: Alluvium and Talus, 2: Misaki Basalt Group (MBG), 3: Saigo Basalt Group (SBG), 4: Omine Basalt Group (OBG), 5: Tsuzurao Quartz Rhyolite Group (TRG), 6: Hei Trachyte Group (HTG), 7: Oki Trachyte-rhyolite Group (OTG), 8: Tsuma Formation (Tertiary sediments), 9: Kori Formation (KF), 10: Tokibariyama Formation, 11: Pre-Tertiary basements (mainly Proterozoic metamorphic rocks). Circles, triangles and squares show localities of samples for younger basalts (MBG, $S B G$ and $O B G), O T G$, and $K F$, respectively. 
intermediate to silicic alkali volcanics, the Oki Trachyte-Rhyolite Group (OTG), the Hei Trachyte Group (HTG) and the Tsuzurao Quartz Rhyolite Group (TRG), erupted in the ascending order (Uchimizu, 1966). OTG is composed of various kinds of rocks ranging from mugearite through trachyte to alkali rhyolite, which are supposed to have erupted successively with no or little time interval from arcuate ring vents (Uchimizu, 1966). The total eruptive volume exceeds $20 \mathrm{~km}^{3}$, and is distributed along the western sector of the island. A K-Ar age of $6.3 \mathrm{Ma}^{*}$ (Kaneoka and Ozima, 1970) and a fission-track age of $3.9 \mathrm{Ma}$ (Suzuki, 1970) are obtained for rhyolitic obsidians belonging to OTG. Iwata et al. (1988) gave a $\mathrm{Rb}-\mathrm{Sr}$ whole rock isochron age of $6.8 \pm 0.2 \mathrm{Ma}$ for ten volcanic rocks ranging from mugearite to rhyolite belonging to OTG. Fujimaki et al. (1989), on the other hand, reported two K-Ar ages of $5.4 \mathrm{Ma}$ for mugearite lavas. Younger felsic volcanic rocks, HTG and TRG, are much smaller in volume than OTG, and are distributed inside the ring vent system of the OTG, in the south-central (HTG) and the northeastern (TRG) part of the island.

Three alkali basalt groups, Omine Basalt Group (OBG), Saigo Basalt Group (SBG) and Misaki Basalt Group (MBG), make up the youngest volcanic groups in the Island (Uchimizu, 1966; Xu, 1988). Some basalt lavas belonging to OBG have moderate to abundant amounts of xenolithic fragments including mantle-derived spinel peridotites (Takahashi, 1978). On the other hand, lavas of SBG and MBG rarely have such xenoliths. K-Ar ages between $4.6 \mathrm{Ma}$ and $3.30 \pm 0.12 \mathrm{Ma}$ are obtained for OBG (Kaneoka et al., 1977; Fujimaki et al., 1989). Hirooka and Kawai (1967) and Kano and Nakano (1985) gave K-Ar ages of $0.85 \mathrm{Ma}^{* *}$ and $1.3 \pm 0.2 \mathrm{Ma}$, respectively for basalt lavas belonging to SBG. MBG, preserving relatively young volcanic landform, is considered to form the youngest volcanic strata in the island

*Recalculated using the current decay constants (Steiger and Jägger, 1977)

${ }^{* *}$ Average of two analyses; $0.823 \pm 0.048 \mathrm{Ma}$ and $0.880 \pm$ $0.035 \mathrm{Ma}$, again recalculated using the current decay constants (Steiger and Jägger, 1977)
(Uchimizu, 1966), but no radiometric information is so far known.

\section{K-Ar DATING}

$\mathrm{K}-\mathrm{Ar}$ dating was done for 15 volcanic rocks in total; 3 lava flows from KF, 3 lava flows and 1 dike rock from OTG, 4 lava flows from OBG, 3 lava flows from SBG, and 1 lava flow from MSG. No attempt has been made on dating volcanic rocks belonging to HTG and TRG. All analyses were done on whole rock samples excluding any visible xenolithic and xenocrystic fragments. Most rocks are fresh with no or little alteration. Three basaltic rocks belonging to the KF are slightly altered, and olivine phenocrysts and groundmass glass (less than a few volume \%) were replaced by clay minerals.

Except for one analysis which was made at Univ. Tokyo, all analyses were done at the Geological Survey of Japan using the following procedure. After crushing and sieving, rock fragments of 16-32 mesh fractions were examined under the binocular microscope not to include any large xenolithic fragments. Aliquots of these rock fragments were further pulverized for potassium analysis. Argon was extracted using a high-vacuum off-line extraction system made of pyrex glass. Eight to ten grams of each sample were weighed into a pre-fired disposable molybdenum crucible and loaded into the extraction system. The line was then baked at $200^{\circ} \mathrm{C}$ under a vacuum for three hours, and samples outside the oven for the glassline were baked overnight at about $100^{\circ} \mathrm{C}$. Crucibles were heated by a radio-frequency induction furnace up to about $1400^{\circ} \mathrm{C}$, and extracted gas was mixed by a known amount of ${ }^{38} \mathrm{Ar}$ spike and was purified by a liquid $\mathrm{N}_{2}$ trap and two Ti getters. Purified noble gas was then collected by a charcoal trap soaked in liquid $\mathrm{N}_{2}$ and detached from the line under a vacuum. Argon isotope analyses were made using a VG Micromass 603 mass spectrometer. Potassium analyses were done by the flame photometry (Matsumoto, 1989). One analysis on OMS was done at Univ. Tokyo following the same procedure with that in Kaneoka and Ozima (1970) 
Table 1. K-Ar ages for volcanic rocks from Oki-Dogo Island

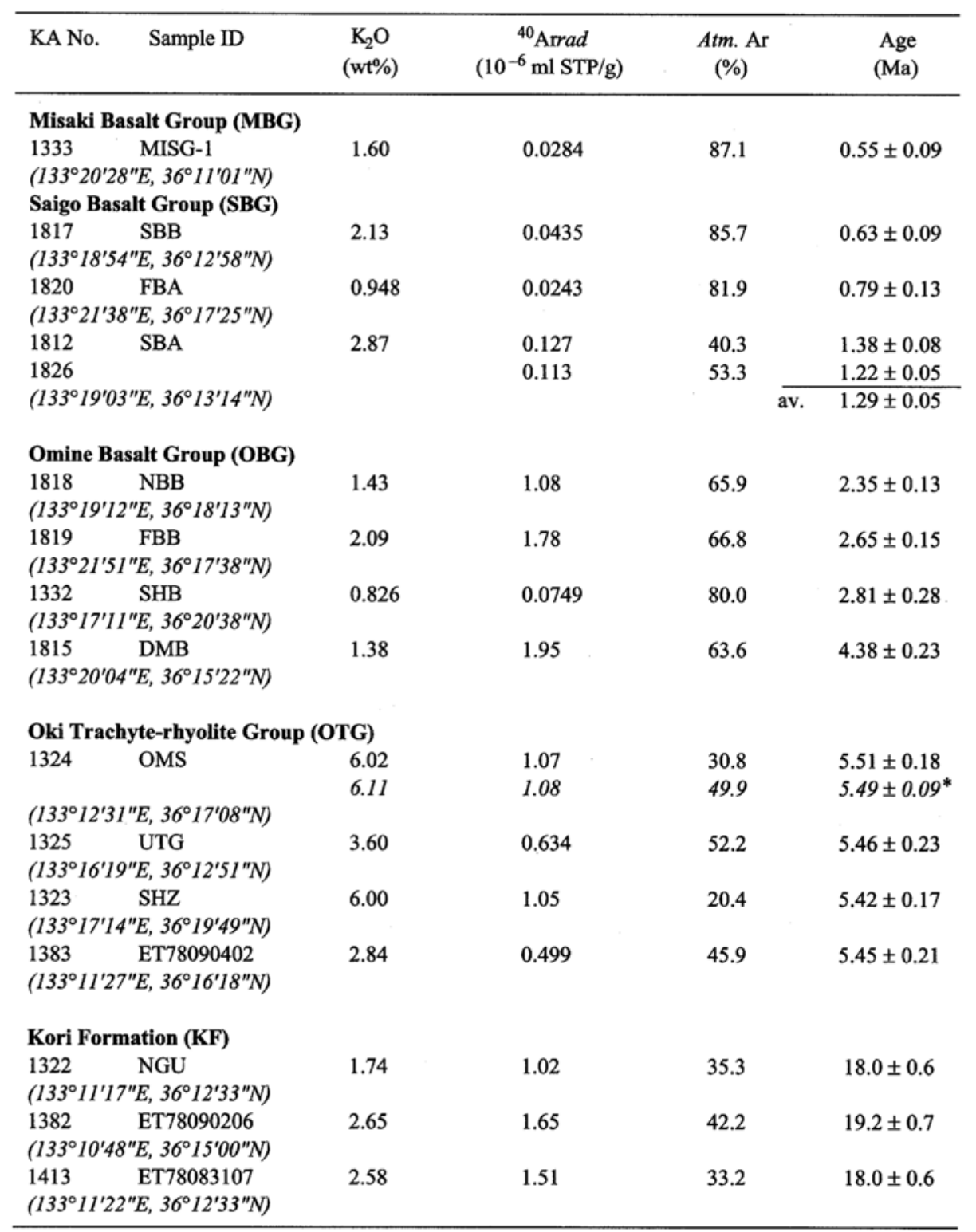

*Dated by I. Kaneoka at Univ. Tokyo.

Others are dated by K. Uto at Geological Survey of Japan (GSJ).

KA No.: laboratory analytical number at GSJ.

$\lambda_{\beta}=4.962 \times 10^{-10} / y, \lambda_{e}=0.581 \times 10^{-10} / y,{ }^{40} \mathrm{~K} / \mathrm{K}=0.01167 \mathrm{~atm} \%$ (Steiger and Jäger, 1977).

Quoted errors are $1 \sigma$.

and Kaneoka et al. (1977).

Analytical results are shown in Table 1. Analytical uncertainties are calculated following the equation of Cox and Dalrymple (1967). Two ages for OMS, one of which was made at GSJ and the other at Univ. Tokyo, agree well each other within analytical uncertainties. This suggests that three previous ages by Kaneoka and Ozima (1970) and Kaneoka et al. (1977) and current ages can be discussed at the same accuracy level. 
Three ages for KF are about 18-19 Ma, which are identical each other within analytical uncertainties. These ages are considered to represent the ages of eruption even though these rocks suffer a little to moderate degrees of alterations, because three rocks give identical ages regardless of the considerable variation in $\mathrm{K}_{2} \mathrm{O}$ contents (1.74$2.65 \mathrm{wt} \%)$. These ages are older than the fissiontrack age of $13.7 \pm 0.7 \mathrm{Ma}$ (Yamazaki and Ganzawa, 1989), but are concordant to the biostratigraphic estimate (Yamazaki et al., 1990, 1991; Yamazaki, 1991).

Four rocks of OTG also gave very concordant ages of 5.42-5.51 Ma. The deviation of ages, 0.09 million years, is much less than analytical uncertainties, 0.18-0.22 million years, for individual ages. These ages are also consistent with the ages of $5.4 \mathrm{Ma}$ for two mugearites by Fujimaki et al. (1989). On the other hand, these ages are considerably younger than the $\mathrm{Rb}-\mathrm{Sr}$ whole rock age, $6.9 \pm 0.3 \mathrm{Ma}$, by Iwata et al. (1988). They are also slightly younger than the K-Ar age, 6.3 Ma, by Kaneoka and Ozima (1970) and older than the fission-track age, 3.6 Ma, by Suzuki (1970). Among four rocks dated in this study, two samples, OMS and UTG, were also used to obtain the Rb-Sr isochron age by Iwata et al. (1988). In addition, the different sample but from the same outcrop from which $\mathrm{SHZ}$ was taken was also used for the $\mathrm{Rb}-\mathrm{Sr}$ dating. The reason for the discrepancy between $\mathrm{K}-\mathrm{Ar}$ and $\mathrm{Rb}-\mathrm{Sr}$ systems will be discussed later.

Four ages for alkali basalt lavas belonging to OBG scatter widely from 4.4 to $2.4 \mathrm{Ma}$, comparing to the tight age grouping for those of OTG. Even though an age for one lava (DMB), $4.38 \pm$ $0.23 \mathrm{Ma}$, is considerably older than other three ages from 2.8 Ma to $2.4 \mathrm{Ma}$, this age agrees well with the age, $4.6 \mathrm{Ma}$ (the average of two analyses; $4.68 \pm 0.21 \mathrm{Ma}$ and $4.51 \pm 0.2 \mathrm{Ma}$ ) for a basalt probably belonging to the same lava unit (Fujimaki et al., 1989). Two ages by Kaneoka et al. (1977), $3.30 \pm 0.12 \mathrm{Ma}$ and $3.6 \mathrm{Ma}$ fill the gap between two age groups. These data suggest that the basalt volcanism of OBG continued intermittently for about two million years from about 4.4 Ma to about 2.4 Ma.

Four other alkali basalt lavas belonging to either SBG or MBG gave ages ranging from $1.30 \pm$ $0.05 \mathrm{Ma}$ to $0.55 \pm 0.09 \mathrm{Ma}, 1.1$ to 1.8 million years younger than the youngest age for OBG far beyond the analytical uncertainties. These ages well agree with previous ages for two basalts of SBG, 0.85 Ma (Hirooka and Kawai, 1967) and $1.3 \pm 0.2 \mathrm{Ma}$ (Kano and Nakano, 1985). The age for MISG-1 belonging to MSG is slightly younger than ages for basalts belonging to SBG, which is concordant with the previous stratigraphy (Uchimizu, 1966; Xu, 1988). The time discrepancy between two groups is, however, negligible if we consider the analytical uncertainties. There has been no logical reason (e.g., petrographical and/or chemical differences) to divide these basaltic rocks into two groups except for the observation that the MBG lava flow, spreading in the southeastern end of this island, preserves the youthful volcanic topography (Uchimizu, 1966). It might be more reasonable to consider that both basalt groups form a continuous single volcanic activity from the view point of $\mathrm{K}$-Ar ages.

As a summary of the present and existing $\mathrm{K}-\mathrm{Ar}$ ages, it is concluded that four cycles of alkali volcanic activity occurred in Oki-Dogo Island in the past 19 million years; $19-18 \mathrm{Ma}, 5.5-5.4 \mathrm{Ma}$, 4.4-2.4 Ma, and 1.3-0.55 Ma. This sporadic and discontinuous volcanism in Oki-Dogo Island contrasts with the relatively instantaneous volcanism at about $6 \mathrm{Ma}$ in the nearby Oki-Dozen Island (Morris et al., 1990; Wada et al., 1990), and none of them are contemporaneous with the volcanic activity in Oki-Dozen Island.

\section{GEOCHEMISTRY}

Even though many major and trace element data have been published (Nakamura et al., 1989, 1990), we add some chemical compositions for dated rocks. The results are shown in Table 2 . Major element data of most rocks were determined by wet chemistry analyzed by $\mathrm{H}$. Haramura in Univ. Tokyo except for a few data obtained by XRF either at Univ. Toronto (Nakamura et al., 


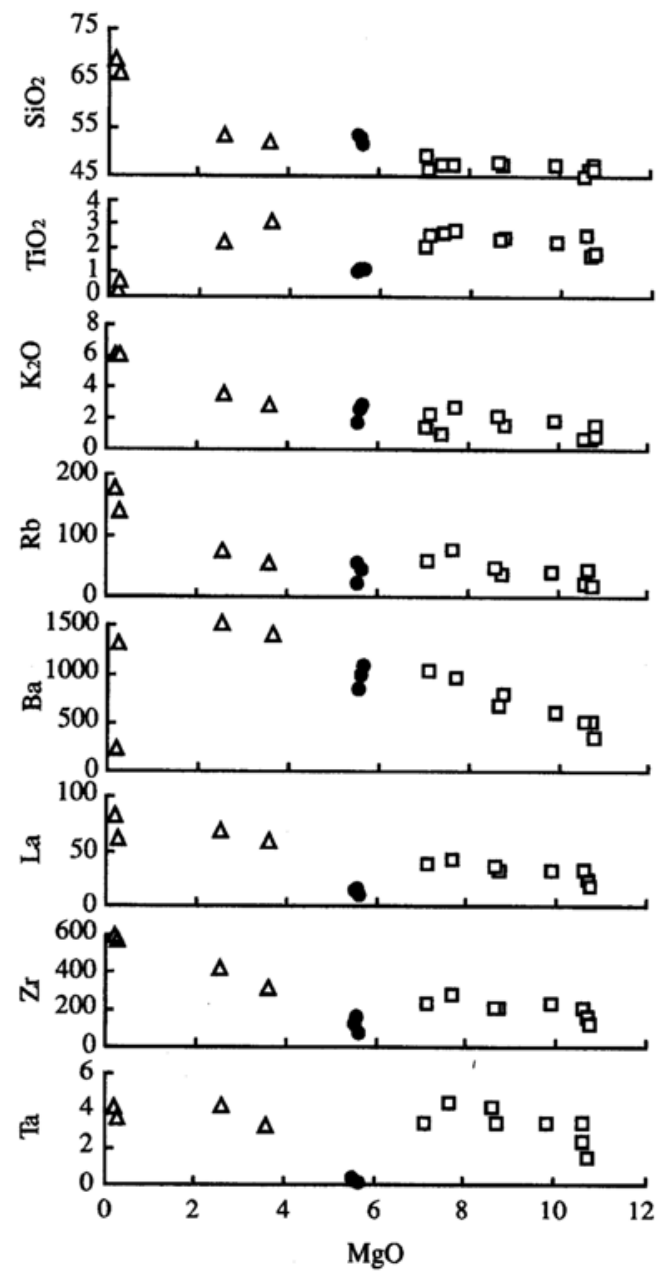

Fig. 3. $\mathrm{MgO}$ variation diagrams for selected major and trace elements. Open squares: Younger basalts (MBG, $S B G, O B G)$; open triangles: OTG; solid circles: $K F$.

1989) or at Univ. Tokyo (Aramaki, 1987). Trace elements were obtained mainly by INAA either at GSJ following the procedure of Tanaka et al. (1988) or at Univ. Toronto together with those given in Nakamura et al. (1989). Some additional elements either by XRF or by isotope dilution are added in Table 2 mainly from the published literature. Details of the credit are given below the table. Some elemental plots and chondrite-normalized REE patterns are shown in Figs. 3 and 4 for selected data from Nakamura et al. (1989, 1990 ) and the current study. It is obvious that the basaltic rocks of $\mathrm{KF}$ are remarkably depleted in HFSE (High-Field Strength Elements) like Ti and Ta compared with younger basaltic rocks. On the other hand, there is no systematic geochemical difference among the three younger basaltic volcanic groups. Mugearites belonging to OTG, having differentiated chemistry (i.e., high $\mathrm{FeO}^{*}$ / $\mathrm{MgO}$ ratios, low $\mathrm{Ni}$ and $\mathrm{Cr}$ contents), have relatively similar incompatible element ratios to the three younger basalt groups.

\section{CONTEMPORANEOUS ERUPTIONS of CoMpositionally DIVERGEd Magmas AT 5.5 Ma}

\section{Magma mixing: false $\mathrm{Rb}-\mathrm{Sr}$ age for OTG}

Rhyolites of Neogene ages with high $\mathrm{Rb}$ but low $\mathrm{Sr}$ contents have great potential to give precise $\mathrm{Rb}-\mathrm{Sr}$ ages even though $\mathrm{Rb}-\mathrm{Sr}$ system is generally applied for older igneous and metamorphic rocks. Radicati di Brozolo et al. (1981) gave $\mathrm{Rb}-\mathrm{Sr}$ mineral isochron ages of about 3.3-3.7 ka for leucite-biotite-pyroxene-whole rock pairs from the Italian high-K volcanics. On the other hand, the caution should be paid if the method is applied to a suite of whole rocks having wide variation in $\mathrm{Rb} / \mathrm{Sr}$ ratios, because these rocks might not have a same initial ${ }^{87} \mathrm{Sr} /{ }^{86} \mathrm{Sr}$ ratio. Wide variations in $\mathrm{Sr}$ isotopic ratios have been reported among recent volcanic products from a single volcano (Notsu et al., 1990; Kurasawa et al., 1986). Kurasawa et al. (1986) reported a $368 \mathrm{Ma} \mathrm{Rb}-\mathrm{Sr}$ "isochron" for volcanic rocks from Quaternary Kirishima volcano, Southwest Japan. Halliday et al. (1989) also gave $\mathrm{Rb}-\mathrm{Sr}$ isochron ages of " $2.09 \pm 0.06,1.90 \pm 0.02$ and $1.14 \pm 0.08 \mathrm{Ma}$ " for pre-caldera rhyolites of Glass Mountain in the Long Valley Caldera, whose $\mathrm{K}$-Ar ages range from 2.1 to $0.79 \mathrm{Ma}$. Kurasawa et al. (1986) attributed the pseudo-isochron to the AFC (assimilation fractional crystallization) process (their "combined process"), while Halliday et al. (1989) interpreted that $\mathrm{Rb}-\mathrm{Sr}$ ages represent ages when the chemical stratifications were formed in the magma chamber.

Iwata et al. (1988) made systematic $\mathrm{Rb}-\mathrm{Sr}$ isotopic studies on a mugurite-trachyte-rhyolite 
Table 2. Major and trace element data for dated volcanic rocks along with other age known basalts from OkiDogo Island

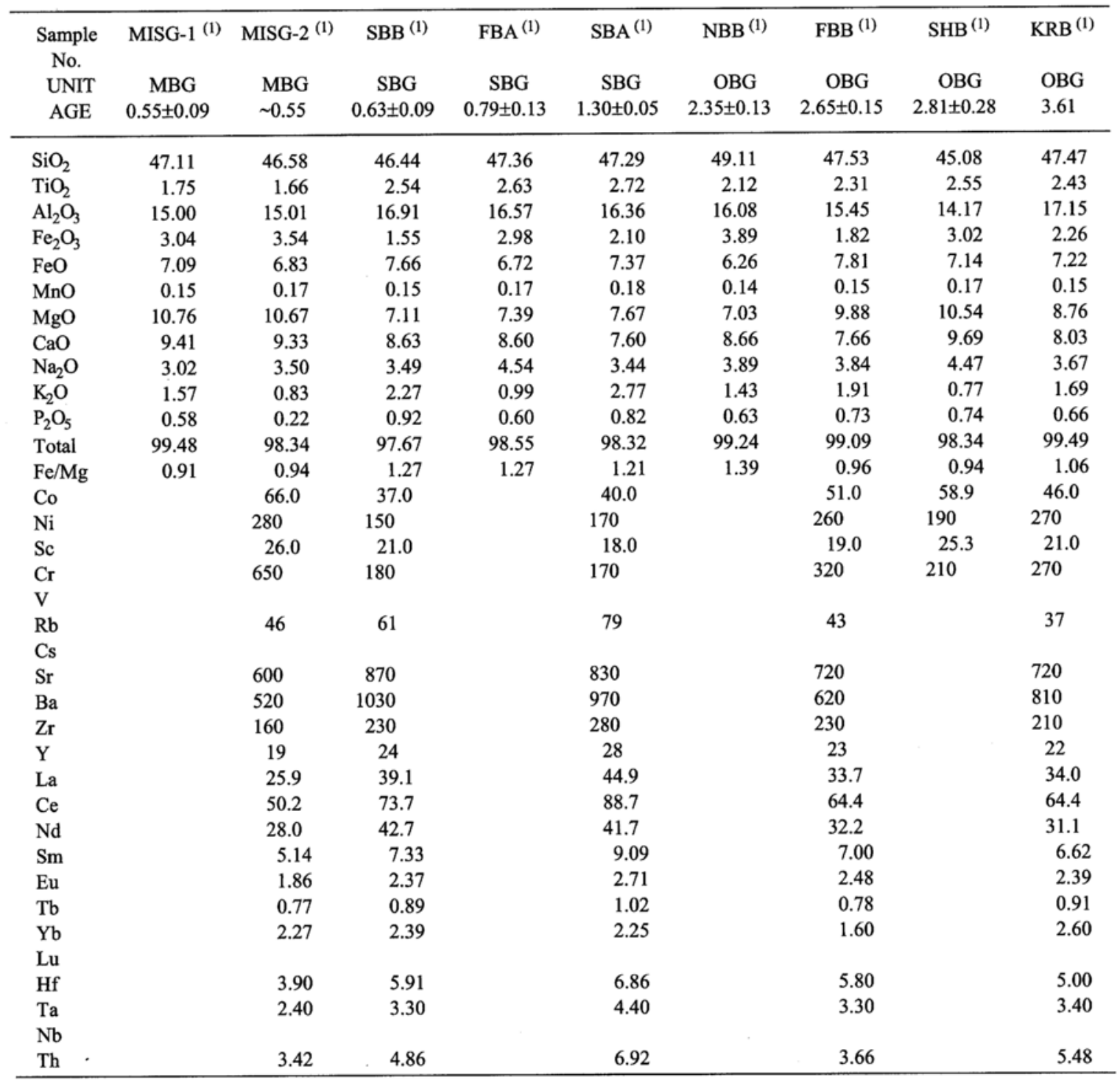

suite belonging to OTG, and obtained a wholerock isochron age of $6.8 \pm 0.3 \mathrm{Ma}$ from ten rocks. They interpreted the age as the time of eruption. On the other hand, K-Ar ages for six rocks belonging to OTG given in this study and Fujimaki et al. (1989) are tightly clustered around 5.5-5.4 $\mathrm{Ma}$, which are significantly younger than the $\mathrm{Rb}-$ $\mathrm{Sr}$ age. As some samples are used for both $\mathrm{K}-\mathrm{Ar}$ and $\mathrm{Rb}-\mathrm{Sr}$ analyses, it should not be appropriate to consider that the OTG volcanism spanned more than a million year from 6.8 Ma to $5.4 \mathrm{Ma}$. As the $\mathrm{Rb}-\mathrm{Sr}$ age was calculated using data analyzed at two laboratories and $\mathrm{K}-\mathrm{Ar}$ ages were from three laboratories, the discrepancy between the $\mathrm{Rb}-\mathrm{Sr}$ and $\mathrm{K}-\mathrm{Ar}$ systems should not be a matter of analytical problems, but rather be a matter of geological interpretation. Here, we claim that the $\mathrm{K}-\mathrm{Ar}$ ages do represent those of eruption but the $\mathrm{Rb}-\mathrm{Sr}$ age is artificial due to magma mixing between basic and acidic magmas. 
Table 2. (continued)

\begin{tabular}{|c|c|c|c|c|c|c|c|c|}
\hline $\begin{array}{c}\text { Sample } \\
\text { No. }\end{array}$ & $\mathrm{OKD}^{(1)}$ & $\mathrm{SHZ}^{(1)}$ & ET7809402 (3) & $\mathrm{UTG}^{(1)}$ & $\mathrm{OMS}^{(1)}$ & ET78083107 (3) & $\mathrm{NGU}^{(2)}$ & ET7809206 ${ }^{(3)}$ \\
\hline UNIT & OBG & OTG & OTG & OTG & OTG & $\mathrm{KF}$ & $\mathrm{KF}$ & $\mathrm{KF}$ \\
\hline AGE & $3.30 \pm 0.12$ & $5.42 \pm 0.17$ & $5.45 \pm 0.21$ & $5.46 \pm 0.23$ & $5.51 \pm 0.18$ & $18.0 \pm 0.6$ & $18.0 \pm 0.6$ & $19.2 \pm 0.7$ \\
\hline $\mathrm{SiO}_{2}$ & 47.79 & 69.01 & 52.00 & 53.57 & 65.83 & 51.50 & 53.36 & 53.04 \\
\hline $\mathrm{TiO}_{2}$ & 2.39 & 0.30 & 3.12 & 2.24 & 0.68 & 1.15 & 1.04 & 1.16 \\
\hline $\mathrm{Al}_{2} \mathrm{O}_{3}$ & 16.44 & 15.50 & 14.56 & 16.29 & 16.54 & 16.83 & 16.14 & 16.00 \\
\hline $\mathrm{Fe}_{2} \mathrm{O}_{3}$ & 1.85 & 2.21 & & 3.65 & 2.19 & & 8.27 & \\
\hline $\mathrm{FeO}$ & 7.14 & 0.19 & 11.28 & 5.45 & 0.68 & 8.59 & & 7.66 \\
\hline $\mathrm{MnO}$ & 0.15 & 0.03 & 0.17 & 0.17 & 0.06 & 0.11 & 0.17 & 0.13 \\
\hline $\mathrm{MgO}$ & 8.63 & 0.19 & 3.61 & 2.57 & 0.27 & 5.64 & 5.53 & 5.57 \\
\hline $\mathrm{CaO}$ & 7.66 & 0.53 & 7.25 & 5.55 & 1.44 & 9.88 & 9.29 & 10.11 \\
\hline $\mathrm{Na}_{2} \mathrm{O}$ & 4.12 & 4.55 & 3.67 & 3.96 & 4.36 & 2.84 & 2.76 & 2.81 \\
\hline $\mathrm{K}_{2} \mathrm{O}$ & 2.23 & 6.06 & 2.90 & 3.64 & 6.11 & 2.88 & 1.75 & 2.70 \\
\hline $\mathrm{P}_{2} \mathrm{O}_{5}$ & 0.81 & 0.05 & 1.39 & 1.01 & 0.13 & 0.52 & 0.41 & 0.77 \\
\hline Total & 99.21 & 98.76 & 99.95 & 98.10 & 98.29 & 99.94 & 98.72 & 99.95 \\
\hline $\mathrm{Fe} / \mathrm{Mg}$ & 1.02 & 11.47 & 3.12 & 3.40 & 9.82 & 1.52 & 1.35 & 1.38 \\
\hline Co & 71.0 & 2.1 & 25.2 & 15.9 & 51.2 & 31.9 & 35.2 & 27.3 \\
\hline $\mathrm{Ni}$ & 200 & 4.0 & 6.4 & 6.5 & 2.9 & 105 & 33.7 & 51 \\
\hline $\mathrm{Sc}$ & 18.0 & 3.9 & 19.4 & 17.3 & 5.12 & 32.0 & 27.4 & 29.4 \\
\hline $\mathrm{Cr}$ & 210 & & 34 & 0.7 & - & 232 & 116 & 116 \\
\hline V & & & 174 & & & 258 & & 244 \\
\hline $\mathrm{Rb}$ & 49 & 181 & 55 & 73 & 138 & 45 & 24 & 57 \\
\hline Cs & & & 0.17 & & & 0.28 & & 0.30 \\
\hline $\mathrm{Sr}$ & 680 & 21 & 680 & 570 & 177 & 745 & 630 & 821 \\
\hline $\mathrm{Ba}$ & 690 & 248 & 1412 & 1530 & 1294 & 1078 & 841 & 993 \\
\hline $\mathrm{Zr}$ & 210 & 598 & 322 & 413 & 571 & 84 & 121 & 163 \\
\hline $\mathrm{Y}$ & 19 & 34 & 39 & 33 & 24 & 19 & 16 & 20 \\
\hline $\mathrm{La}$ & 38.9 & 83.2 & 61.0 & 68.2 & 61.4 & 10.6 & 16.2 & 17.7 \\
\hline $\mathrm{Ce}$ & 75.0 & 124.0 & 130.6 & 130 & 99.6 & 22.3 & 33.2 & 38.3 \\
\hline $\mathrm{Nd}$ & 27.7 & 46.5 & 54.9 & 59.8 & 44.9 & 12.9 & 14.3 & 15.5 \\
\hline Sm & 7.34 & 8.57 & 11.9 & 11.3 & 7.13 & 3.02 & 3.56 & 4.48 \\
\hline $\mathrm{Eu}$ & 2.33 & 0.79 & 4.66 & 4.03 & 1.34 & 1.21 & 1.10 & 1.47 \\
\hline $\mathrm{Tb}$ & 0.74 & 1.13 & 2.47 & 1.34 & 0.84 & 0.72 & 0.39 & 0.88 \\
\hline $\mathrm{Yb}$ & 2.43 & 3.28 & 2.50 & 2.86 & 2.73 & 1.62 & 1.68 & 1.73 \\
\hline $\mathrm{Lu}$ & & & 0.35 & & & 0.23 & & 0.25 \\
\hline $\mathrm{Hf}$ & 5.78 & 15.50 & 7.76 & 10.0 & 13.9 & 2.26 & 3.42 & 3.97 \\
\hline $\mathrm{Ta}$ & 4.20 & 4.14 & 3.20 & 4.15 & 3.45 & $0.1>$ & 0.33 & 0.27 \\
\hline $\mathrm{Nb}$ & & & 48 & & & 3.6 & & 5.2 \\
\hline Th & 5.61 & 25.60 & 6.59 & 10.10 & 16.7 & 0.83 & 3.67 & 2.79 \\
\hline
\end{tabular}

(l) Major elements: wet chemistry (by H. Haramura), trace elements: INAA and XRF (Univ. Toronto).

${ }^{(2)}$ Major elements: XRF (Univ. Toronto), trace elements: INAA and XRF (Univ. Toronto).

${ }^{(3)}$ Major elements: XRF (Univ. Tokyo), trace elements: INAA and XRF (GSJ).

It is always cautioned in the text books of isotope geology that one should be very careful in discriminating a real isochron from a two-component mixing line in the isochron diagram (see Chapter 9 of Faure, 1986). A ${ }^{87} \mathrm{Sr} /{ }^{86} \mathrm{Sr}-1 / \mathrm{Sr}$ diagram is commonly used to identify whether a linear line in a ${ }^{87} \mathrm{Sr} /{ }^{86} \mathrm{Sr}-{ }^{87} \mathrm{Rb} /{ }^{86} \mathrm{Sr}$ isochron diagram is a real isochron or just a mixing line. If a suite of rocks initially had a same ${ }^{87} \mathrm{Sr} /{ }^{86} \mathrm{Sr}$ ratio but has various ${ }^{87} \mathrm{Rb} /{ }^{86} \mathrm{Sr}$ ratios, it should not necessarily form a single line in a ${ }^{87} \mathrm{Sr} /{ }^{86} \mathrm{Sr}-1 / \mathrm{Sr}$ diagram after the $\mathrm{Rb}$-Sr clock started. On the other hand, if a suite of rocks is formed by binary mixing between two end members with different ${ }^{87} \mathrm{Sr} /{ }^{86} \mathrm{Sr}$ ratios, it should make a linear line not only in a ${ }^{87} \mathrm{Sr} /{ }^{86} \mathrm{Sr}-{ }^{87} \mathrm{Rb} /{ }^{86} \mathrm{Sr}$ diagram but also in a ${ }^{87} \mathrm{Sr} /$ 
(a) 1000

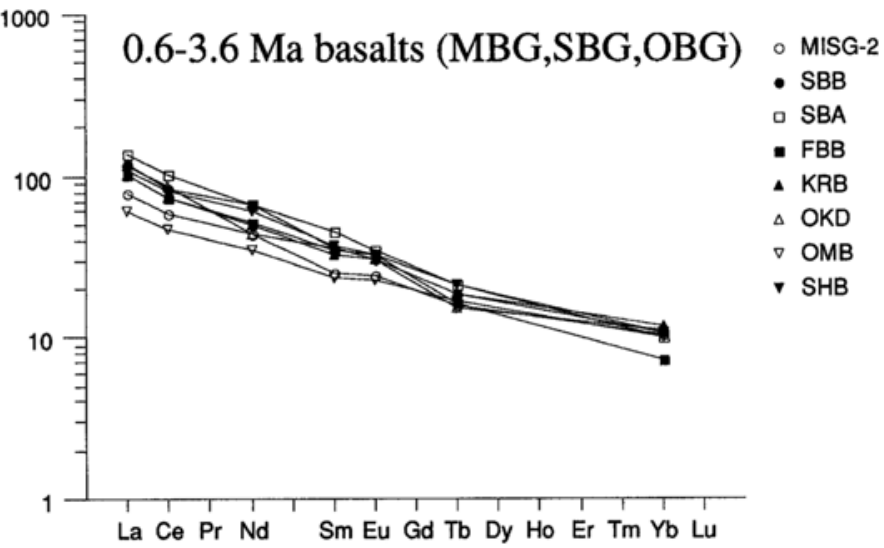

(b)

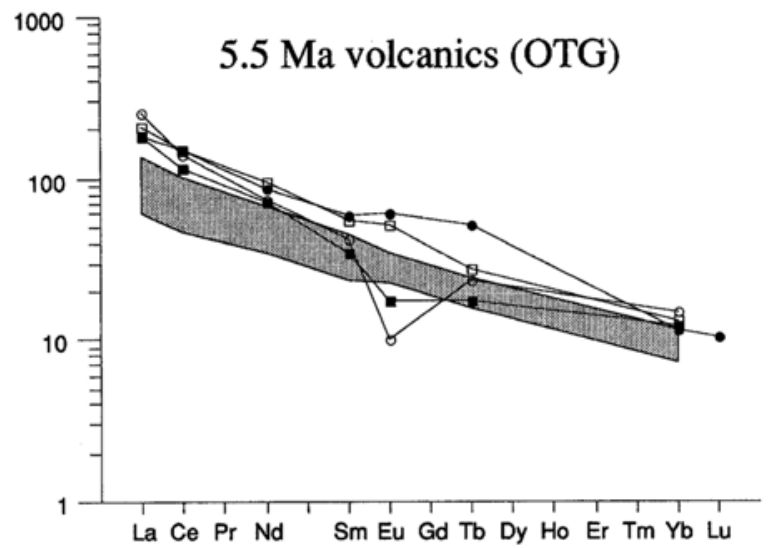

(c)

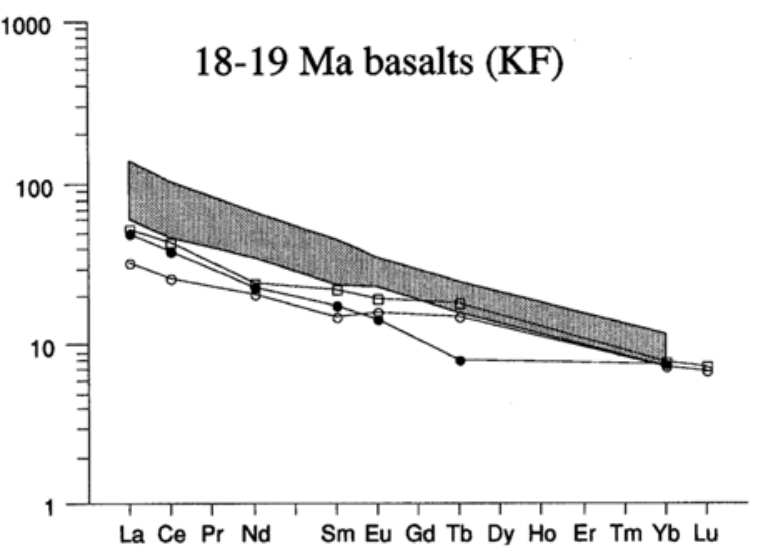

Fig. 4. Chondrite-normalized REE patterns. Shaded zones in (b) and (c) show the variational range for the younger basalts in (a). Chondrite values are from Nakamura (1974).

${ }^{86} \mathrm{Sr}-1 / \mathrm{Sr}$ diagram (Faure, 1986). In the case of the $\mathrm{Rb}-\mathrm{Sr}$ system of OTG, it naturally has an actual age component at least of $5.5 \mathrm{Ma}$. We, thus, should consider the correlation of "excess" com- ponent of the system; i.e., ${ }^{87} \mathrm{Sr} /{ }^{86} \mathrm{Sr}$ ratios at 5.5 Ma (solid squares in Fig. 5(a)). A straight mixing line is drawn between mugearites-trachytes and rhyolites in a ${ }^{87} \mathrm{Sr} /{ }^{86} \mathrm{Sr}-1 / \mathrm{Sr}$ diagram (Fig. 5(b)). 
a)

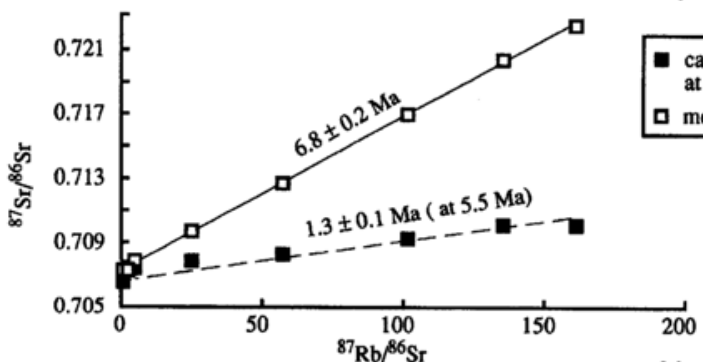

calculated value at $5.5 \mathrm{Ma}$

measured values

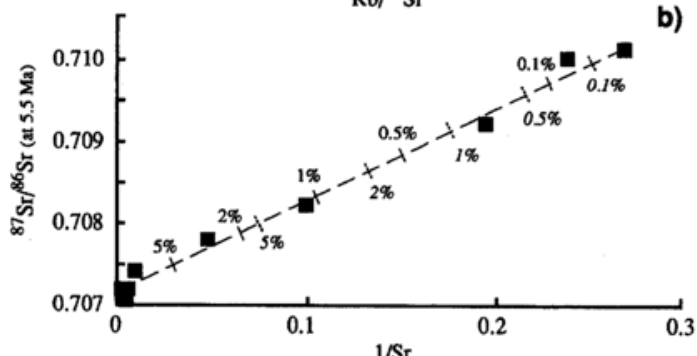

b)
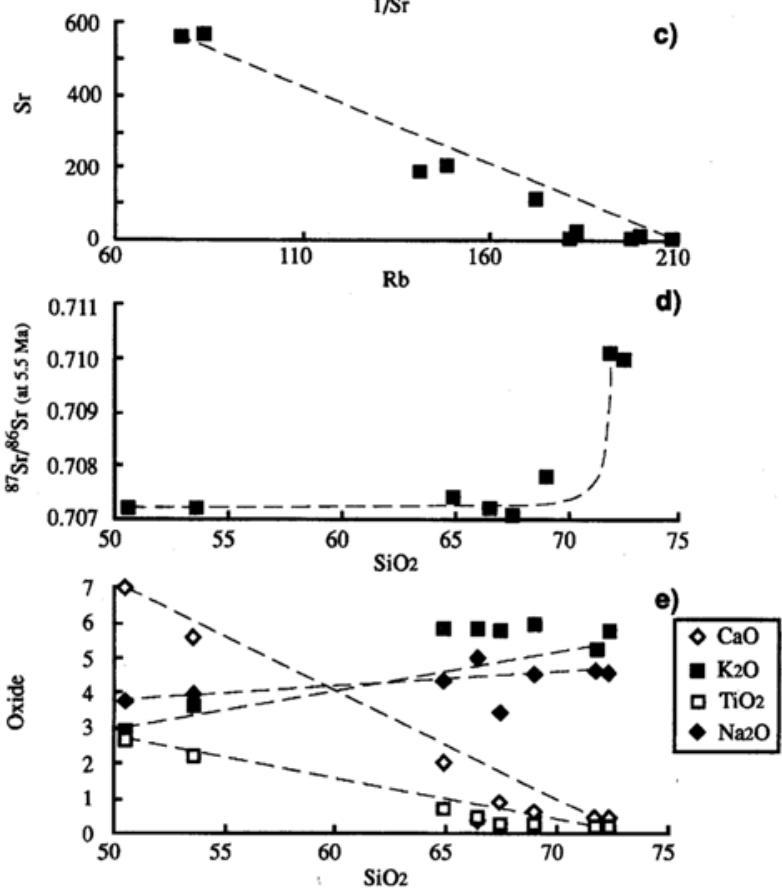

Fig. 5. Diagrams showing the evidence of magma mixing for mugearites, trachytes and rhyolites belonging to OTG. a): $\mathrm{Rb}$-Sr isochron diagram. Open squares show the present day ${ }^{87} \mathrm{Sr}{ }^{86} \mathrm{Sr}$ ratios $\left({ }^{87} \mathrm{Sr}^{86} \mathrm{Sr}_{\mathrm{p}}\right)$, giving the age of $6.8 \pm 0.3 \mathrm{Ma}$ (Iwata et al., 1988), while solid squares are ratios at $5.5 \mathrm{Ma}\left[{ }^{87} \mathrm{Sr}^{86} \mathrm{Sr}(5.5 \mathrm{Ma})\right] . \quad$ b): ${ }^{87} \mathrm{Sr} /$ ${ }^{86} \mathrm{Sr}_{(5.5 \mathrm{Ma})}$ vs. $1 / \mathrm{Sr}$ relationship. Solid tick marks with plain texts show mixing ratios between a mugearite with $50 \mathrm{wt} \% \mathrm{SiO}_{2}$ and a rhyolite with $72 \mathrm{wt} \% \mathrm{SiO}_{2}$, while dotted marks with italic texts are those between trachytes with 66-67 wt\% $\mathrm{SiO}_{2}$ and a rhyolite. c): $\mathrm{Sr}$ vs. $\mathrm{Rb}$ concentration relationship. d): ${ }^{87} \mathrm{Sr}^{86} \mathrm{Sr}_{(5.5 \mathrm{Ma})}$ vs. $\mathrm{SiO}_{2}$ relationship. Solid line is a calculated binary mixing line between basic and acidic end members. e): Silica variation diagrams for selected oxides $\left(\mathrm{K}_{2} \mathrm{O}, \mathrm{TiO}_{2}\right.$ and $\left.\mathrm{Na}_{2} \mathrm{O}\right)$. All data plotted in these diagrams are for the same samples used to calculate the $\mathrm{Rb}-\mathrm{Sr}$ isochron age by Iwata et al. (1988). ${ }^{87} \mathrm{Sr} /{ }^{86} \mathrm{Sr}$ ratios and $\mathrm{Rb}$ and $\mathrm{Sr}$ contents are taken from Iwata et al. (1988), and major element concentrations are from Kurasawa (1984), this study and unpublished data of E. Takahashi. Mixing line shown in b)-e) is a calculated one between two end members, having maximum and minimum ${ }^{87} \mathrm{Sr} / 86 \mathrm{Sr}$ ratios (No. 9 and No. 14 of Iwata et al., 1988). 
Solid tick marks with plain texts show mixing ratios between a mugearite with $50 \mathrm{wt} \% \mathrm{SiO}_{2}$ and a rhyolite with $72 \mathrm{wt} \% \mathrm{SiO}_{2}$, while dotted marks with italic texts are those between trachytes with 66-67 wt $\% \mathrm{SiO}_{2}$ and a rhyolite. Since there is a negligible variation between mugearites and trachytes in Figs. 5(a) and 5(b), the basic end member which actually mixed with rhyolites could be either mugearites or trachytes. In addition to this diagram, a binary mixing line should be drawn in any element-element diagrams in the case of magma mixing. Some diagrams are also shown in Figs. 5(c)-(e). Clear mixing lines are again drawn among these volcanic rocks except for $\mathrm{K}_{2} \mathrm{O}$. In the $\mathrm{K}_{2} \mathrm{O}$ variation, a relatively good correlation exists between trachytes and rhyolites. This might suggest that the real magma mixing could have happened between trachytes and rhyolites but not between mugearites and rhyolites. Further petrographic studies should be necessary to determine which is the basic end member for magma mixing, mugearite or thracyte. Nevertheless, magma mixing between mugearites or trachytes and rhyolites is proved to be a possible mechanism to form a pseudo-isochron in the $\mathrm{Rb}-\mathrm{Sr}$ isotopic system.

\section{Basaltic magma influx for the composite magma eruptions}

Mugearites, differentiated basaltic rocks having $50-52 \mathrm{wt} \% \mathrm{SiO}_{2}$, in Oki-Dogo Island were once considered to belong to the OBG (Uchimizu, 1966; Xu, 1988). Iwata et al. (1988) was the first to recognize the genetic relationship between such mugearites and trachyte-rhyolites of OTG based on their $\mathrm{Rb}-\mathrm{Sr}$ isotopic study. Fujimaki et al. (1989, 1991), on the other hand, considered that these mugearites should compose an independent volcanic group stratigraphically between OTG and OBG. Our current study, however, elucidated that these mugearites should be included into OTG as was already mentioned. It should be emphasized that basaltic magmas, even though moderately differentiated in mafic minerals, had played an important role on the evolution and eruption of highly differentiated trachyte and alkali rhyolite magmas. These mugearites, erupted between older LILE-enriched basalts and younger OIB-type basalts, are very important in considering the temporal variations of basalt geochemistry in OkiDogo Island.

\section{"ARC-TYPE" VOLCANICS WITH HIGH LILE/HFSE RATIOS AND Its Tectonic Significance}

As was mentioned above, basalts and andesites of 18-19 Ma have high LILE/HFSE ratios, which are usually believed to be a characteristic signature for volcanic rocks erupted in the subduction zone. There are, however, some lines of circumstantial evidence to suggest that these volcanic rocks did not erupt in the tectonic setting of active subduction zone but rather inside the back-arc rift system:

(1) As was already reviewed, the existence of Early Proterozoic gneiss in Oki-Dogo Island is considered to indicate that this island is one of continental fragments, which was left behind the Japanese Island during the opening of the Japan. There is an E-W trending volcano-tectonic graben, named Shindi folded belt, between Oki-Dogo Island and the mainland SW Japan, and it represents the southernmost end of the back-arc rift system related to the opening of the Japan Sea. The Japan Sea was supposed to be in the middle of active opening when HFSE-depleted basaltic rocks erupted at $18-19 \mathrm{Ma}$ in Oki-Dogo Island. The HFSE-depleted basaltic rocks in Oki-Dogo are, thus, considered to have erupted on the structural high inside the back-arc rift system during the extensional basin and range formations.

(2) Far southward in Shikoku Island, closer to the Nankai Trough, $\mathrm{CO}_{2}$-rich lamprophyre dikes intruded at $17.7 \pm 0.5 \mathrm{Ma}$ (Uto et al., 1987), almost at the same time when the HFSE-depleted alkalic rocks erupted in Oki-Dogo. These dike rocks are highly $\mathrm{SiO}_{2}$ undersaturated alkalic rocks, carrying abundant ultramafic nodules (Goto and Arai, 1987). No HFSE depletion nor LILE enrichment in these lamprophyres (Uto, unpublished) excludes the possibility of the supply of the LILEenriched fluids from the downgoing oceanic slab 
to the wedge mantle of Southwest Japan at 18 Ma. Uto et al. (1987) suggested that the northern Philippine Sea Plate was under the final stage of spreading and should not have subducted beneath Southwest Japan when the lamprophyre dikes intruded into Shikoku Island. The boundary between the Philippine Sea Plate and Southwest Japan was considered to be a transform fault (Uto et al., 1987).

(3) The occurrence of HFSE-depleted and LILE-enrich basalts is not necessarily limited to subduction zones and some of such basalts do occur in non-island-arc tectonic environments, such as in extensional continental interior (e.g., Rio Grande Rift: Dungan et al., 1986; Big Pine volcanic field: Ormerod et al., 1991; Colorado River Trough: Bradshaw et al., 1993). Geochemical characteristics of the 18-19 Ma basalts in OkiDogo should not be enough to define the tectonic setting of the island when these basalts erupted. In addition, the basaltic rocks of $\mathrm{KF}$ are enriched only in $\mathrm{K}_{2} \mathrm{O}$ and $\mathrm{Ba}$, but not in $\mathrm{Rb}$, Cs, LREE and $\mathrm{Th}$, comparing with alkalic basalts in the active island-arc.

What is the origin for the high LILE/HFSE ratios in alkali volcanic rocks in Oki-Dogo? The following may be one possible mechanism.

The upper mantle lithosphere beneath the OkiDogo Island had been contaminated by subduction fluids for long time at the Asian continental margin before the opening of the Japan Sea. Hydrous minerals like phlogopite and/or amphibole should have been formed due to the metasomatic reaction between lithospheric mantle and subduction fluids. Phlogopite is a mineral known to be very rich in $\mathrm{K}$ and $\mathrm{Ba}$, but not in LREE, Th and HFSE (Giannetti and Luhr, 1990). Menzies et al. (1987; Fig. 5(d)) showed the normalized trace-element pattern enriched in $\mathrm{K}, \mathrm{Ba}$ and $\mathrm{Sr}$ but not in LREE, Th and HFSE for a glimmerite; "phlogopite-rich nodule with variable amounts of clinopyroxene and/or ilmenite" (Erlank et al., 1987). If subduction-related fluid reacted with lithospheric mantle to form phlogopite, $\mathrm{Ba}, \mathrm{K}$ and $\mathrm{Sr}$ should have been selectively trapped in phlogopite-bearing peridotites, but LREE, Th and HFSE should not. During formation of many horst and graben systems in the back-arc region, the continental lithosphere should have been stretched and thinned. Thinned lithosphere should also have been heated by the upwelling asthenosphere as is now observed in the Basin and Range region in western USA. When contaminated mantle was heated, it might have partially melted and supplied Ba- and K-enriched magmas to the surface or at least contaminated $\mathrm{Ba}$ and $\mathrm{K}$ easily during the ascent of magmas originated from the asthenosphere. Similar process is suggested to explain the origin of $\mathrm{Nb}$ - and $\mathrm{Ta}$ depleted basalts in the Basin and Range region, United States (Ormerod et al., 1991; Bradshaw et al., 1993).

\section{TEMPORAL VARIATION IN BASALT GEOCHEMISTRY}

There are five volcanic groups accompanying eruptions of alkali basaltic rocks in Oki-Dogo Islands; KF, OTG, OBG, SBG and MBG. Xu (1988) and Fujimaki et al. (1991) made geochemical studies on these basaltic rocks in term of trace element and $\mathrm{Sr}$ isotopes. Their main observations are; (1) significant difference in geochemistry, especially of LILE/HFSE ratios between basalts of $\mathrm{KF}$ and those of younger three basalt groups, (2) the occurrence of some basaltic rocks having high $\mathrm{Na}_{2} \mathrm{O} / \mathrm{K}_{2} \mathrm{O}$ ratios only in OMB, (3) general geochemical similarities between mugearites and younger basalts, and (4) ${ }^{87} \mathrm{Sr} /{ }^{86} \mathrm{Sr}$ initial ratios of volcanics generally decrease with the decreasing age of eruption.

In the current study, we clarified the age relationships of these basalts. In addition, we added concentrations of some trace elements, especially of REE, which Xu (1988) did not present. The temporal variations of some element/element ratios are shown in Fig. 6. Spidergrams of these rocks are also shown in Fig. 7. From these diagrams, followings are significant:

(1) There is a big gap not only in geochemistry but also in ages of activity between KF and younger four volcanic groups. As younger volcanic groups are geochemically similar to each other 


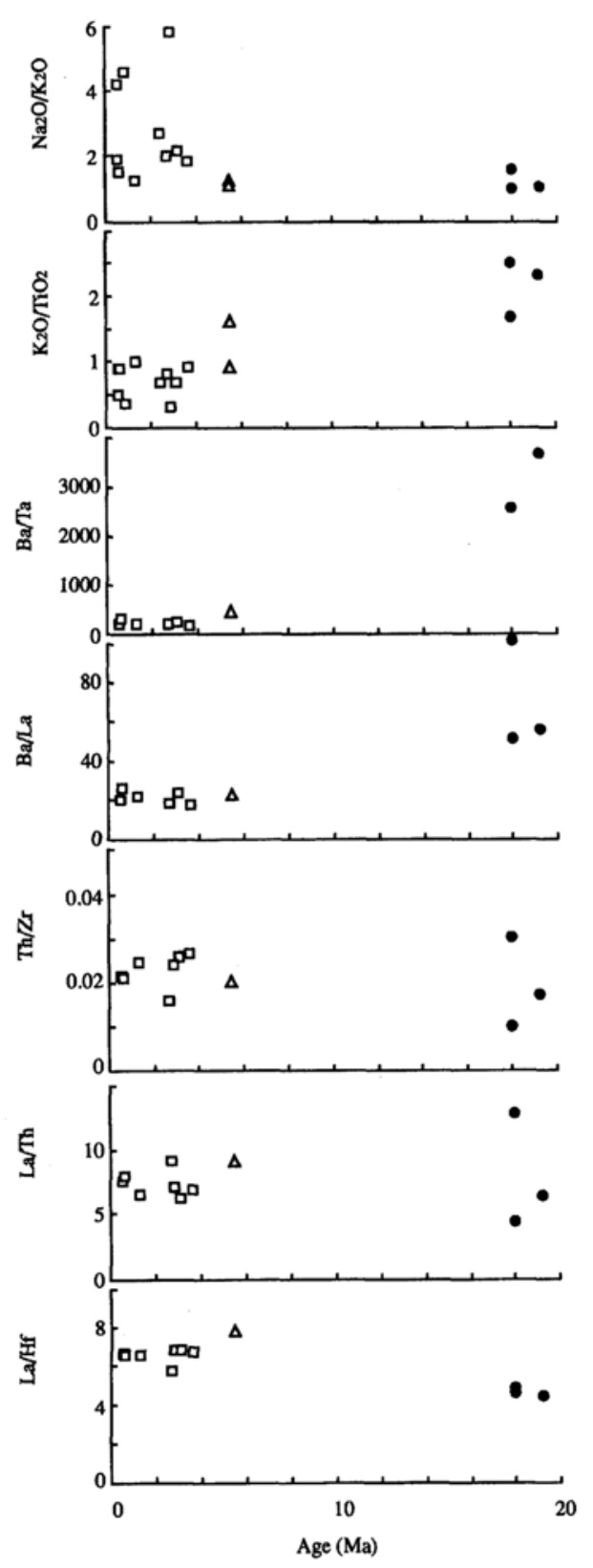

Fig. 6. Temporal variations in some element/element ratios for basaltic rocks in Oki-Dogo Island. Solid circles: $K F$, open triangles: $O T G$, open squares: $O B G$, $S B G$, and $M B G$.

including mugearites of OTG, the temporal variation in basalt geochemistry in Oki-Dogo Island should be appropriately expressed as the geochemical discontinuity between Early Miocene basalts and Pliocene-Pleistocene ones.

(2) Mugearites of OTG have element/element ratios similar to younger basalt groups, suggesting that a parental basalt magma for chemically diverged OTG is similar to younger ones, but is different from the Miocene basalts.

(3) Even though there are significant differences in some LILE/HFSE ratios, such as $\mathrm{K}_{2} \mathrm{O} / \mathrm{TiO}_{2}, \mathrm{Ba} / \mathrm{Ta}$ and $\mathrm{Ba} / \mathrm{La}$, some ratios like $\mathrm{Th} / \mathrm{Zr}, \mathrm{La} / \mathrm{Th}$ and $\mathrm{La} / \mathrm{Hf}$ show no significant variations between the basalts of $\mathrm{KF}$ and younger basalts.

(4) Basalts with high $\mathrm{Na}_{2} \mathrm{O} / \mathrm{K}_{2} \mathrm{O}$ ratios are not restricted to OBG as suggested by Xu (1988), but also appear in younger SBG and MBG.

Since all elements, except for $\mathrm{Na}_{2} \mathrm{O}$, plotted in Fig. 6 are moderately to highly incompatible ones, these element/element ratios may have not been modified significantly during fractional crystallization from a single parental magma. The variation of such ratios, thus, should roughly reflect that of primary magmas. In addition, there is a large difference in $\mathrm{TiO}_{2} / \mathrm{K}_{2} \mathrm{O}, \mathrm{Ba} / \mathrm{Ta}$ and $\mathrm{Ba} / \mathrm{La}$ between older and younger basalts even though $\mathrm{Th} / \mathrm{Zr}, \mathrm{La} / \mathrm{Th}$ and $\mathrm{La} / \mathrm{Hf}$ ratios are generally similar between the two. This suggests that the source mantle materials are significantly different between older and younger basalts especially in terms of $\mathrm{Ba}$ and $\mathrm{K}_{2} \mathrm{O}$.

As has already been suggested by Nakamura et al. (1989), the Pliocene-Pleistocene alkali basalts in Oki-Dogo Island have intraplate geochemical affinity (Fig. 7) and have been little affected by subduction-related fluids. On the other hand, the Early Miocene basalts have high ratios in some LILE/HFSE ratios similar to those of subductionrelated Quaternary basalts in NE Japan. These Early Miocene basalts, however, are not considered to have erupted in an active subduction zone as mentioned in the previous chapter. It is, thus, considered that the temporal variation in the source mantle materials should not be due to the recent addition or subtraction of subduction-related fluids to the originally homogeneous mantle.

As has been mentioned before, the volcanic rocks of $\mathrm{KF}$ erupted in the middle of back-arc 

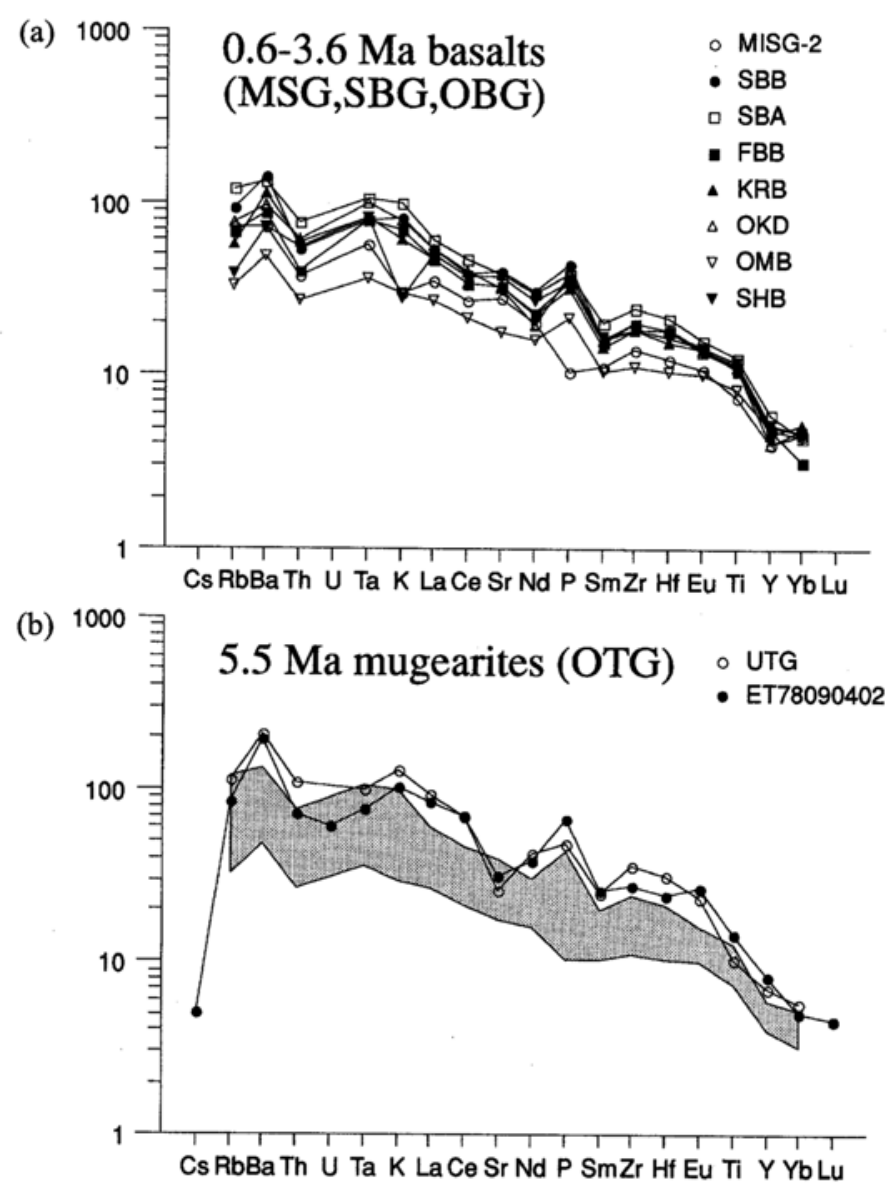

(c)

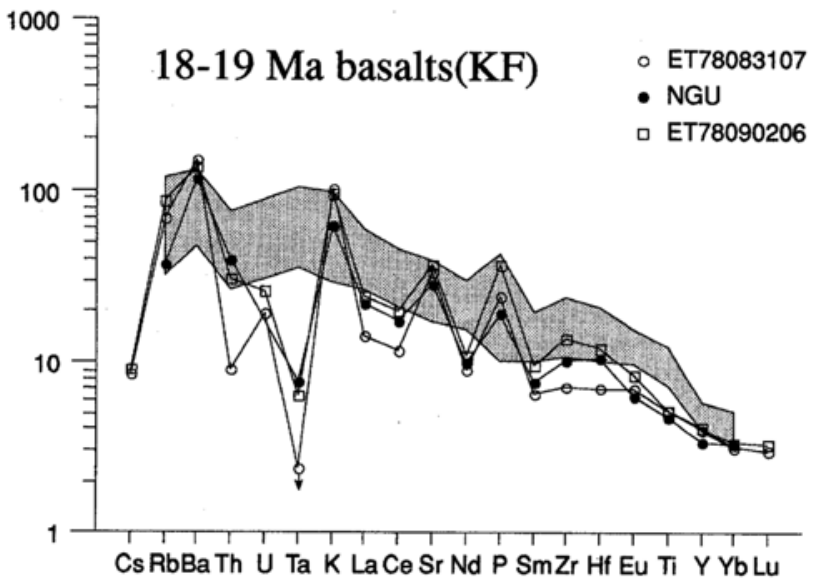

Fig. 7. Primitive mantle-normalized spidergrams. Primitive mantle values are from Sun and McDonough (1989). Shaded zones in (b) and (c) show the variational range for younger basalts in (a). 
opening while the younger basalts did considerably after the cessation of the opening. The big difference in basalt geochemistry should somewhat reflect the difference in tectonic environment when these basalts erupted. According to Ormerod et al. (1991) and Bradshaw et al. (1993), there are time progressive chemical variations from the high LILE/HFSE syn-extensional basalts with high ${ }^{87} \mathrm{Sr} /{ }^{86} \mathrm{Sr}$ to the low LILE/HFSE post-extensional basalts with lower ${ }^{87} \mathrm{Sr} /{ }^{86} \mathrm{Sr}$ at some basaltic provinces in the Basin and Range, western United States. These authors suggest the time progressive change in source materials from the lithospheric mantle to the asthenospheric mantle. Such a relationship might also be the case for the origin of temporal difference in source mantle geochemistry in Oki-Dogo Island, because the islands is built on the Proterozoic continental lithosphere. The Miocene basalts might be originated from the lithospheric mantle when the lithospheric thinning was proceeding during the active back-arc rifting, while the Pliocene-Pleistocene basalts are from the asthenospheric mantle or the deeper plume mantle (Nakamura et al., 1989) after the thinned lithosphere has cooled sufficiently not to contaminate the upwelling magmas.

As for the origin of $\mathrm{Na}_{2} \mathrm{O} / \mathrm{K}_{2} \mathrm{O}$ variation among younger basalts, there should have been conditions of magma generation at multiple depths beneath Oki-Dogo Island during Pliocene-Pleistocene time. This is because that $\mathrm{Na}_{2} \mathrm{O}$ content in primary magmas generated from mantle peridotite varies significantly depending on the $P-T$ conditions of partial melting (e.g., Takahashi and Kushiro, 1983).

\section{Conclusions}

(1) Alkalic volcanism took place discontinuously for four times in Oki-Dogo Island; 19-18 Ma, 5.5-5.4 Ma, 4.3-2.4 and 1.3-0.6 Ma, and there was a significantly long repose period of volcanic activity between 18-5.5 Ma.

(2) Chemically diverged magmas from mugearites to alkali rhyolites erupted in a relatively short period at $5.5 \mathrm{Ma}$. The previously reported
$\mathrm{Rb}-\mathrm{Sr}$ whole rock age of $6.8 \mathrm{Ma}$ does not represent the age of eruption, but rather has some pseudo-isochron component, which is due to the magma mixing between mugearite/trachyte and rhyolite. Simultaneous eruption of mugearites, differentiated alkali basalt magmas, with trachytes and rhyolites suggests that a basaltic magma influx was important for the formation and eruption of compositionally diverged magmas.

(3) There is a big difference in geochemistry between the 19-18 Ma basalts and younger basalts; the former have LILE/HFSE $\left(\mathrm{K}_{2} \mathrm{O} / \mathrm{TiO}_{2}, \mathrm{Ba} / \mathrm{Ta}\right.$ etc.) ratios significantly higher than the latter.

(4) Basalts of 19-18 Ma erupted on a structural high made up of Proterozoic lithosphere inside the back-arc rift system, when the opening of the Japan Sea was ongoing and no oceanic plate was subducting beneath the Oki-Dogo. LILE-enriched characteristics of these basalts may be due to the considerable contribution of phlogopite-enriched continental lithosphere, which had been contaminated by subduction-related fluids for a considerable time at the Asian continental margin.

(5) Pliocene-Pleistocene basalts, erupted considerably after the cessation of the opening of the Japan Sea, may be derived from the asthenosphere or the deeper plume mantle geochemically similar to the source materials for Oceanic Island Basalts.

Acknowledgments - The authors would like to express their sincere appreciation to Mr. Hiroshi Haramura for his skillful wet chemical analyses on many volcanic rocks. We are grateful to Professor Shigeo Aramaki for allowing us to use his XRF facility, and also to Dr. Hiroaki Sato for his careful review and editorial handling. One of the authors (K.U.) thank Ken Shibata, Tsuyoshi Tanaka, Shigeko Togashi and Kazuhiko Kano for their encouragement and suggestions during his geochronological and geochemical studies on alkali basalt volcanism of SW Japan. He also appreciate the assistance and help from Shigeru Uchiumi, Tadao Nakagawa and Hideki Aoyama.

\section{REFERENCES}

Aramaki, S. (1987) Geological background of the lethal gas bursts from Lake Nyos, Cameroon, August 1986. Bull. Volcanol. Soc. Jpn., Ser. 2 32, 57-72 (in Japanese with English abstract). 
Bradshaw, T. K., Hawkesworth, C. J. and Gallagher, K. (1993) Basaltic volcanism in the Southern Basin and Range: no role for a mantle plume. Earth Planet. Sci. Lett. 116, 45-62.

Cox, A. and Dalrymple, G. B. (1967) Statistical analysis of geomagnetic reversal data and the precision of Potassium-Argon dating. J. Geophys. Res. 72, 2603 2614.

Dungan, M. A., Lindstrom, M. M., McMillan, N. J., Moorbath, S., Hoefs, J. and Haskins, L. A. (1986) Open system magmatic evolution of the Taos Plateau volcanic field, northern New Mexico. 1. The petrology and geochemistry of the Servilleta Basalt. $J$. Geophys. Res. 91, 5999-6028.

Erlank, A. J., Waters, F. G., Hawkesworth, C. J., Haggerty, S. E., Allsopp, H. L., Rickard, R. S. and Menzies, M. A. (1987) Evidence for mantle metasomatism in peridotite nodules from the Kimberley Pipes, South Africa. Mantle Metasomatism (Menzies, M. A. and Hawkesworth, C. J., eds.), 221-311, Academic Press, London.

Faure, G. (1986) Principles of Isotope Geology (second edition). John Wiley \& Sons, Inc., New York, $589 \mathrm{pp}$.

Fujimaki, H., Xu, H. and Aoki, K. (1989) K-Ar dating of mugearites from Dogo, Oki island, Shimane Prefecture, southwestern Japan. J. Mineral. Petrol. Economic Geol. 84, 335-338 (in Japanese with English abstract).

Fujimaki, H., Xu, H. and Aoki, K. (1991) Temporal variations of $\mathrm{Sr}$ isotopic compositions for the rocks from Dogo, Oki islands, Shimane Prefecture. $J$. Mineral. Petrol. Economic Geol. 86, 16-26 (in Japanese with English abstract).

Giannetti, B. and Luhr, J. F. (1990) Phlogopiteclinopyroxene nodules from high-K magmas, Roccamonfina Volcano, Italy: evidence for a lowpressure metasomatic origin. Earth Planet. Sci. Lett. 101, 404-424.

Goto, K. and Arai, S. (1987) Petrology of xenoliths in lamprophyre from Shingu, Southwest Japan: implication for origin of Fe-rich mantle peridotites. Mineral. Petrol. 37, 137-155.

Halliday, A. N., Mahood, G. A., Holden, P., Metz, J. M., Dempster, T. J. and Davidson, J. P. (1989) Evidence for long residence times of rhyolites magma in the Long Valley magmatic system: the isotopic record in precaldera lavas of Glass Mountain. Earth Planet. Sci. Lett. 94, 274-290.

Hirooka, K. and Kawai, N. (1967) Results of age determination of some late Cenozoic rocks. $1967 \mathrm{An}$ nual Progress Rept., Paleogephys. Res. Jpn. 69-73, Osaka.

Ishida, H. (1985) Stratigraphy of alkaline rocks in western part of Dogo, Oki Islands. Geol. Rept. Shimane Univ. 4, 69-79 (in Japanese with English abstract).

Iwata, M., Kagami, H., Takahashi, E. and Kurasawa, H. (1988) The Rb-Sr whole rock isochron age and genesis of Oki Trachyte-Rhyolite Group in Oki Dogo Island. Bull. Volcanol. Soc. Jpn. 33, 79-86 (in Japanese with English abstract).

Jolivet, L. and Tamaki, K. (1992) Neogene Kinematics in the Japan Sea region and volcanic activity of the Northeast Japan arc. Proccedings of the Ocean Drilling Programs, Scientific Results (Tamaki, K., Suyehiro, K., Allan, J., Mcwilliams, M. et al., eds.), College Station, TX, 127/128, Part 2, 1311-1331.

Kaneoka, I., Notsu, K., Takigami, Y. and Fujioka, K. (1990) Constraints on the evolution of the Japan Sea based on ${ }^{40} \mathrm{Ar}-{ }^{39} \mathrm{Ar}$ ages and $\mathrm{Sr}$ isotopic ratios for volcanic rocks of the Yamato seamount chain in the Japan Sea. Earth Planet. Sci. Lett. 97, 211-225.

Kaneoka, I. and Ozima, M. (1970) On the radiometric ages of volcanic rocks from Japan. Bull. Volcanol. Soc. Jpn., Ser. 2 15, 10-21 (in Japanese with English abstract).

Kaneoka, I., Takahashi, E. and Zashu, S. (1977) K-Ar dating of alkali basalts from the Oki-Dogo island. $J$. Geol. Soc. Jpn. 83, 187-189 (in Japanese).

Kaneoka, I., Takigami, Y., Takaoka, N., Yamashita, S. and Tamaki, K. (1992) ${ }^{40} \mathrm{Ar}-{ }^{39} \mathrm{Ar}$ analysis of volcanic rocks recovered from the Japan Sea floor: constraints on the age of formation of the Japan Sea. Proceedings of the Ocean Drilling Programs, Scientific Results (Tamaki, K., Suyehiro, K., Allan, J., Mcwilliams, M. et al., eds.), College Station, TX, 127/128, Part 2, 819-835.

Kano, K. (1991) Volcaniclastic sedimentation in a shallow-water marginal basin: the Early Miocene Koura Formation, SW Japan. Sediment. Geol. 74, 309-321.

Kano, K., Kato, H., Yanagisawa, Y. and Yoshida, F. (1991) Stratigraphy and geologic history of the Cenozoic of Japan. Geol. Surv. Jpn. Rept. No. 274, 114 pp. (in Japanese with English abstract).

Kano, K. and Nakano, S. (1985) Stratigraphic correlation of the Neogene in the San-in district, southwest Japan, in the light of radiometric dating. Bull. Geol. Surv. Jpn. 36, 427-438 (in Japanese with English abstract).

Kano, K. and Yoshida, F. (1985) Geology of the Sakaiminato District. Quadrangle series, scale 1:50,000, Geol. Surv. Jpn., 57 pp. (in Japanese with English abstract, 5 pp).

Kurasawa, H. (1984) Strontium isotopic ratios of the volcanic rocks from Dogo of the Oki Islands, Japan. J. Mineral. Petrol. Economic Geol. 79, 484-497 (in 
Japanese with English abstract).

Kurasawa, H., Fujinawa, A. and Leeman, W. P. (1986) Calc-alkaline and tholeiitic rock series magmas coexisting within volcanoes in Japanese Island arcsStrontium isotopic study. J. Geol. Soc. Jpn. 92, 255268 (in Japanese with English abstract).

Matsumoto, A. (1989) Improvement for determination of potassium in K-Ar dating. Bull. Geol. Surv. Jpn. 40, 65-70.

Menzies, M. A., Rogers, N., Tindle, A. and Hawkesworth, C. J. (1987) Metasomatic and enrichment processes in lithospheric peridotites, an effect of asthenosphere-lithosphere interaction. Mantle Metasomatism (Menzies, M. A. and Hawkesworth, C. J., eds.), 313-361, Academic Press, London.

Morris, P. A., Itaya, T., Watanabe, T. and Yamauchi, S. (1990) Potassium/argon ages of Cenozoic igneous rocks from eastern Shimane Prefecture-Oki Dozen Islands, Southwest Japan and the Japan Sea opening. J. Southeast Asian Earth Sci. 4, 125-131.

Nakamura, E., Campbell, I. H., McCulloch, M. T. and Sun, S.-S. (1989) Chemical geodynamics in a back arc region around the Sea of Japan: implications for the genesis of alkaline basalts in Japan, Korea, and China. J. Geophys. Res. 94, B4, 46344654.

Nakamura, E., McCulloch, M. T. and Campbell, I. H. (1990) Chemical geodynamics in the back arc region of Japan based on the trace element and $\mathrm{Sr}-\mathrm{Nd}$ isotopic compositions. Tectonophys. 174, 207-233.

Nakamura, N. (1974) Determination of REE, Ba, Fe, $\mathrm{Mg}, \mathrm{Na}$ and $\mathrm{K}$ in carbonaceous and ordinary chondrites. Geochim. Cosmochim. Acta 38, 757-775.

Notsu, K., Arakawa, Y. and Kobayashi, Y. (1990) Strontium isotopic characteristics of arc volcanic rocks at the initial stage of subduction in western Japan. J. Volcanol. Geotherm. Res. 40, 181-196.

Ormerod, D. S., Rogers, N. W. and Hawkesworth, C. J. (1991) Melting in the lithospheric mantle: Inverse modelling of alkali-olivine basalts from the Big Pine Volcanic Field, California. Contrib. Mineral. Petrol. 108, 305-317.

Otofuji, Y., Hayashida, A. and Torii, M. (1985) When was the Japan Sea opened?: paleomagnetic evidence from southwest Japan. Formation of Active Ocean Margins (Nasu et al., eds.), 551-566, TERRAPUB, Tokyo.

Otuka, Y. (1939) Tertiary crustal deformations in Japan (with short remarks on Tertiary paleogeography). Jubilee Publ. Commem. Prof. Yabe's 60th Birthday 481-519.

Radicati di Brozolo, F., Huneke, J. C., Papanastassiu, D. A. and Wasserburg, G. J. (1981) ${ }^{40} \mathrm{Ar}-{ }^{39} \mathrm{Ar}$ and $\mathrm{Rb}-\mathrm{Sr}$ age determinations on Quaternary volcanic rocks. Earth Planet. Sci. Lett. 53, 445-456.
Steiger, R. H. and Jäger, E. (1977) Subcomission on Geochronology: convention on the use of constants in geo- and cosmochronology. Earth Planet. Sci. Lett. 36, 359-362.

Sun, S.-S. and McDonough, W. F. (1989) Chemical and isotopic systematics of oceanic basalts: implication for mantle composition and processes. Magmatism in the Ocean Basins (Saunders, A. D. and Norry, M. J., eds.), Geol. Soc. Special Publ., No. 42, 313-345.

Suzuki, M. (1970) Fission track ages and uranium contents of obsidian. J. Anthrop. Soc. Nippon 78, 5058 (in Japanese with English abstract).

Tainosho, Y., Shibata, K. and Uchiumi, S. (1991) Granitic rocks in Dogo, Oki Islands, Shimane Prefecture, Japan. J. Geol. Soc. Jpn. 97, 53-60 (in Japanese with English abstract).

Takahashi, E. (1978) Petrologic model of the crust and upper mantle of the Japanese island arcs. Bull. Volcanol. 414, 529-546.

Takahashi, E. and Kushiro, I. (1983) Melting of a dry peridotite at high pressures and basalt magma genesis. Am. Mineral. 68, 859-879.

Tamaki, K. (1986) Age estimation of the Japan Sea on the basis of stratigraphy, basement depth, and heat flow data. J. Geomag. Geoelectr. 38, 427-446.

Tamaki, K. (1988) Geological structure of the Japan Sea and its tectonic implications. Bull. Geol. Surv. Jpn. 39, 269-365.

Tanaka, T. and Hoshino, M. (1987) Sm-Nd ages of Oki metamorphic rocks and their geological significance. The 94th Annual Meeting, Geol. Soc. Jpn., Abstract 492 (in Japanese).

Tanaka, T., Kamioka, H. and Yamanaka, K. (1988) A fully automated $\gamma$-ray counting and data processing system for INAA and analysis of rock reference samples. Bull. Geol. Surv. Jpn. 39, 537-557 (in Japanese with English abstract).

Tanaka, T. and Ogusa, K. (1981) Structural movement since middle Miocene in the offshore San-in sedimentary basin, the Sea of Japan. J. Geol. Soc. Jpn. 87, 725-736 (in Japanese with English abstract).

Tiba, T. (1975) Geology of Dozen, Oki Islands. Bull. Natn. Sci. Mus., Ser C 1, 137-145 (in Japanese with English abstract).

Uchimizu, M. (1966) Geology and petrology of alkali rocks from Dogo, Oki Islands. J. Fac. Sci., Univ. Tokyo, Ser. II 16, 85-159.

Uto, K. (1989) Neogene volcanism of Southwest Japan: its time and space based on $\mathrm{K}-\mathrm{Ar}$ dating. Ph.D. Thesis, 184 pp., Univ. Tokyo, Tokyo.

Uto, K., Hirai, H., Goto, K. and Arai, S. (1987) K-Ar ages of carbonate- and mantle nodule-bearing lamprophyre dikes from Shingu, central Shikoku, 
Southwest Japan. Geochem. J. 21, 283-290.

Wada, Y., Itaya, T. and Ui, T. (1990) K-Ar ages of Oki-Dozen and Tango dike swarms, western Honshu, Japan. Bull. Volcanol. Soc. Jpn. Ser. 2 35, 217-229 (in Japanese with English abstract).

$\mathrm{Xu}, \mathrm{H}$. (1988) Petrology and geochemistry of the alkali rocks from Dogo, Oki Islands, Shimane Prefecture, Southwestern Japan. Sci. Rept., Tohoku Univ., Ser. III 17, 1-106.

Yamauchi, S. and Yoshitani, A. (1981) Tectonic movements in the progressive stage of the GreenTuff basins-Taking the case of the Miocene series in the eastern part of Shimane Prefecture, western Japan. J. Geol. Soc. Jpn. 87, 711-724 (in Japanese with English abstract).

Yamazaki, H. (1991) Cenozoic stratigraphy on the north of Saigo Bay, southern part of Oki-Dogo Island, Southwest Japan. J. Geol. Soc. Jpn. 97, 917-930 (in Japanese with English abstract).

Yamazaki, H. and Ganzawa, Y. (1989) Fission track ages of the Tertiary Kori and Yui Formations in Dogo, Oki Islands, West Japan. J. Geol. Soc. Jpn. 95, 619-622 (in Japanese).

Yamazaki, H., Shitasue, M. and Takayasu, K. (1991) Re-examination of stratigraphic relationship between the Miocene Kori and Kumi Formations in Dogo, Oki Islands, West Japan. Earth Sci. 45, 177-190 (in Japanese with English abstract).

Yamazaki, H., Takayasu, K. and Shitasue, M. (1990) Daitom fossils of Early Miocene from Oki Dogo, and its significance. Proc. Kansai Branch, Geol. Soc. Jpn. No. 109, 11-12 (in Japanese). 